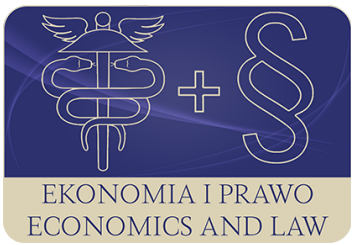

EKONOMIA I PRAWO. ECONOMICS AND LAW

Volume 20, Issue 4, December 2021

p-ISSN 1898-2255, e-ISSN 2392-1625

www.economicsandlaw.pl

ORIGINAL ARTICLE

received 31.05.2021; revised 01.12.2021; accepted 31.12.2021

Citation: Hajdys, D. (2021). Problems of financing sources for environmental protection in strategic documents of the European Union and Poland in the new financial perspective for 2021-2027.

Ekonomia i Prawo. Economics and Law, 20(4), 745-761. https://doi.org/10.12775/EiP.2021.044.

\title{
Problems of financing sources for environmental protection in strategic documents of the European Union and Poland in the new financial perspective for 2021-2027
}

\author{
DAGMARA HAJDYS \\ University of Lodz, Faculty of Economics and Sociology, Institute of Finance, \\ ul. Rewolucji 1905 r. 39, 90 -214 Lódź, Poland \\ ๑dagmara.hajdys@uni.lodz.pl \\ (D) orcid.org/0000-0001-6371-5423
}

\begin{abstract}
Motivation: Over the past two decades, the world, and Poland with it, has faced a huge challenge of transforming its economy towards climate neutrality. The observed effects of climate change, such as abrupt weather changes (prolonged droughts, sudden downpours), increase in average temperatures, environmental pollution, call for systemic and social actions. It should be clearly noted that the responsibility for actions aimed at environmental protection is borne not only by public administration (central and local government), but also by the private sector, as the one using and influencing the environment. The year 2020 brought an unexpected global health crisis caused by the SARS$\mathrm{CoV}-2$ virus. MFF procedures developed up to that time were modified. The COVID-19 pandemic significantly affected the preparation of legislation, programs, and rules for obtaining funds from them for project implementation. Many legislative works have been postponed, causing delays. The fact of the pandemic has led to the implementation of the Instrument for Reconstruction and Enhancing Resilience, which includes largescale financial support for public investments and areas such as green and digital projects, in addition to the regular financial perspective. Support will be provided in the form of loans (EUR 360 billion) and grants (EUR 312.5 billion).
\end{abstract}


Aim: The aim of the study is to compare the financial instruments covered by the European Union financial perspectives 2021-2027 with 2014-2020 in the context of environmental funding sources in Poland.

Results: Both in the financial perspective 2014-2020 and the new one for 2021-2027, environmental protection issues are one of the main priorities. The continuity of previous structural funds has been preserved and supplemented with new instruments in response

to the unprecedented socio-economic situation that has arisen as a result of the global health crisis caused by the SARS-CoV-2 pandemic. As a result of negotiations, EUR 76 billion will be made available to Poland under the EU's cohesion policy and the Fund for Equitable Transformation, whereas in the previous one the amount was EUR 85.2 billion. The allocation of funds and the directions of spending will not only result from Poland's development needs, but also (and perhaps above all) from the modified priorities of the Union as a response to the health situation of the EU community after the pandemic and the continuation of existing activities related to research, innovation, digitization, climate and the environment. The launch of individual programmes will allow ongoing analysis and evaluation of both the solutions adopted in strategic documents and their effects.

Keywords: European Union; structural funds; multiannual financial framework; environmental protection

JEL: F02; O52; G28; R58

\section{Introduction}

Over the past two decades, the world, and Poland with it, has faced a huge challenge of transforming its economy towards climate neutrality. The observed effects of climate change, such as abrupt weather changes (prolonged droughts, torrential downpours), increase in average temperatures, environmental pollution, induce systemic and social actions. It should be clearly pointed out that the responsibility for activities directed at environmental protection is borne not only by public administration (central and local government), but also by the private sector, as the one using and influencing the environment. We should not forget about households, which in recent years, through the system of various fees, indirectly participate in financing the activities for the improvement of the state of the environment.

It is no secret that activities in the field of environmental protection require investments, which in turn require appropriate financial resources. Therefore, long-term strategies of activities concerning environmental protection, in which tools for implementation and sources of financing are indicated, become so important.

The aim of the study is to compare the financial instruments covered by the European Union financial perspectives 2021-2027 with 2014-2020 in the context of environmental funding sources in Poland. 


\section{Literature review}

Dynamic changes in civilization have led to excessive strain on the ecosystem. Progressing on an unprecedented scale, environmental degradation translates into multi-faceted damage, including economic, social and natural. Therefore, it is not surprising that decision makers unanimously declare to take actions and promote behaviors aimed at protecting natural resources.

Environmental protection is understood as a set of activities aiming at the rational shaping of the environment and management of its resources (natural goods) in accordance with the principle of sustainable development, as well as counteracting the creation of pollution and preventing its harmful effects on the environment. Undertakings serving the environmental protection have mainly the investment character but they can also be non-investment activities, e.g. educational ones. The protection of the environment also includes the abandonment of already conducted economic activities that may increase adverse phenomena in the ecosystem (Kożuch, 2018, p. 62).

These activities are necessary and are aimed at ensuring favorable living conditions for the present and future generations, as well as realizing the right to use natural resources and preserving the value of the environment (Rubaszkiewicz, 2008, p. 13).

Environmental protection is also defined as a set of ideas, measures and activities aimed at maintaining the environment in a state providing optimal conditions for human life and ensuring the continuity of the most important processes occurring in the biosphere as a basis for human consumption and production activities. The purpose of environmental protection is to prevent and counteract negative impacts on the environment that cause destruction, damage, pollution or physical changes in the elements of nature (Dobrzańska et al., 2021, pp. 36-37).

The last decade has seen a dynamic and multidirectional development of pro-ecological projects aimed at reducing adverse climate change, protecting natural resources, air, biodiversity of species (Macherzyński \& Nowodziński, 2017, p. 53). This is facilitated by the tools of pro-environmental policy used by the state, which include instruments of legal, financial and organizational nature. The different instruments are closely related to each other (Scheme 1).

The actions taken require considerable financial outlays. The financial resources allocated for financing pro-ecological undertakings may take various forms, the choice of which depends on: the type of undertaking (investment or educational activity), the status of the applicant (enterprise, budgetary unit, natural person), the type of financing institution (bank, ecological fund, central or local budget) (Kożuch, 2007, p. 114).

In Poland, there is a synergic system of financing environmental projects, based on domestic sources (fees and penalties) and foreign sources (funds from operational programs under EU policies or funds transferred under international agreements). In the literature, one can find different divisions of sources 
of financing pro-environmental investments. The commonly dominant division of sources of financing of environmental protection tasks includes: budgetary, private and foreign funds (Barczak \& Kowalewska, 2014, p. 39; Kłos, 2015, p. 130; Jura, 2015, p. 85). Moreover, sources are divided into internal and external (Augusewicz et al., 2012, p. 22; Barczak \& Kowalewska, 2014, p. 85). In turn, Burzyńska (2012, p. 254) additionally divides the system of financing environmental protection according to the institutional criterion. According to him, the public sector includes: state budget and budgets of local government units, environmental purpose funds, environmental foundations, state banks and state enterprises. The private sector includes enterprises, commercial banks, leasing companies, investment funds, environmental foundations, households and foreign financial institutions.

Financing environmental protection can be generally presented as the use of four basic groups of methods (or their combinations) (Gabryś, 2007, p. 187; Graczyk, 2002, p. 329): investors' own funds, financial liabilities (credits, loans, bonds, leasing), equity (shares and stocks in companies), subsidies. The basic instruments of the financial system are: ecological taxes and fees, ecological penalties, subsidies, preferential credits, loans, redemption of part of the loan amount, tax reliefs, marketable investment credits, loans, bonds, leasing, equity shares (Burzyńska, 2012, p. 254; Fiedor, 2002, p. 293). Financial tools can directly or indirectly affect the environmental management system. The former by incorporating environmental costs and benefits into the price. The latter indirectly affect prices through a system of taxes and fees (Poskrobko, 1998, p. 237; Wasiuta, 2015, p. 230) (Scheme 2). Direct tools include environmental charges, while indirect tools include taxes and fees (Rutkowska \& Poplawski, 2017, p. 49). Direct tools include environmental charges, while indirect tools include taxes and fees (Rutkowska \& Poplawski, 2017, p. 49).

Investments in environmental protection are mainly carried out by local governments, state budget units, national parks, entrepreneurs and private persons. The pillars of the system are environmental funds, i.e. the National Fund for Environmental Protection and Water Management (NFEP\&WM/ NFOŚiGW) and Provincial Funds for Environmental Protection and Water Management (PFEP\&WM/WFOŚiGW).

\subsection{Environmental protection in the European Union's multiannual financial framework for 2021-2027}

So far the Multiannual Financial Framework (MFF) has been adopted six times including the one for 2021-2027. Under the Treaty of Lisbon (2007) the document was transformed from an interinstitutional agreement into a regulation. The MFF sets out the rules with which the Union's budget must comply in order to ensure financial discipline. In May 2018 European Commission (2021a) presented legislative proposals for a new financial framework for 2021-2027. 
Unexpectedly, the year 2020 brought a global health crisis caused by the SARS-CoV-2 virus. The COVID-19 pandemic significantly affected the preparation of legislation, programs, and rules for obtaining funds from them for the implementation of investment projects. Many legislative works were postponed, causing delays. The fact of the pandemic has led to the implementation of the Recovery and Resilience Facility (RRF) in addition to the regular financial perspective. Following this, on 27 May 2020. Commission presented the Next Generation EU, which included revised proposals for the MFF and own resources.

On 17 December 2020 the Council adopted a regulation (Council Regulation, 2020) laying down the EU's multiannual financial framework for the period 2021-2027. The regulation establishes a long-term EU-27 budget of EUR 1,074.3 billion and provides for the inclusion of the European Development Fund. Together with the EU's new Next Generation EU Recovery Facility worth nearly EUR 750 billion. In total, the Union will gain resources in the unprecedented amount of EUR 1.8 billion for the coming years, to be used for the socio-economic recovery of the Member States after the Covid-19 pandemic and the implementation of long-term priorities in various EU policies.

The EU budget for 2021-2027 focuses on six pillars: 1) single market, innovation and digital economy, 2) economic, social and territorial cohesion, 3) natural resources and environment, 4) migration and border management, 5) security and defense, and 6) neighborhood and world (Table 1) (European Commission, 2021a).

The Next Generation EU is a new temporary instrument that aims to address the economic and social damage caused by the coronavirus pandemic. The premise is that post COVID-19 Europe will be greener, more digital, more resilient and better adapted to current and future challenges.

Most of the Next Generation EU (EUR 672.5 billion) will be spent under the Recovery and Resilience Facility (RRF). The RRF includes large-scale financial support for public investments and areas such as green and digital projects. Support will be provided in the form of loans (EUR 360 billion) and grants (EUR 312.5 billion).

More than $50 \%$ of the amount will support modernisation, for example through:

- research and innovation, via Horizon Europe;

- fair climate and digital transitions, via the Just Transition Fund and the Digital Europe Programme;

- preparedness, recovery and resilience, via the Recovery and Resilience Facility, rescEU and a new health programme, EU4Health.

In addition, the package pays attention to: modernising traditional policies such as cohesion and the common agricultural policy, to maximise their contribution to the Union's priorities, fighting climate change, with $30 \%$ of the EU funds, (the highest share ever of the European budget), biodiversity protection and gender equality (European Commission, 2021b). 
Funding will be available through programs:

- European Regional Development Fund (ERDF), which aims to strengthen social and economic cohesion of the EU by reducing disparities in the development of European regions;

- the Cohesion Fund (CF), related to the reduction of current economic and social disparities, promotion of sustainable development through the implementation of strategic projects in the areas of environmental protection and transport;

- European Social Fund+, which aims to respond to labour market and social challenges and to stimulate sustainable economic development by investing in human capital. ESF + will be a combination of several instruments that operated separately in the 2014-2020 financial perspective, respectively: European Social Fund and Youth Initiative (YEI);

- the European Fund for Aid to the Most Deprived (FEAD) and the European Programme for Employment and Social Innovation (EaSI);

- the EU Maritime and Fisheries Fund (EMFF), which aims to support coastal communities;

- the Just Transition Fund, directed at activities related to mitigating the social and economic impacts of the energy transition.

Environmental activities will be financed under the Multiannual Financial Framework (MFF) with an amount of EUR 356 billion and the Next Generation EU with an amount of EUR 15.5 billion. A total of EUR 374 billion has been earmarked for environmental activities. Under the third pillar: natural resources and environment, the budget amounted to EUR 373.9 billion, including EUR 22.8 billion for environment and climate. Funds for pro-environmental investments will flow from the Cohesion Fund, European Agricultural Fund for Rural Development.

In the new financial perspective, the EU has created a new Fair Transition Fund to support high-carbon regions that will be most affected by the transition to a climate-neutral economy. It will receive funding of EUR 7.5 billion under the EU budget and EUR 10 billion under the Next Generation EU. The continuation of the Environment and Climate Action Programme (LIFE), with EUR 4.8 billion has been maintained (European Council, 2021).

\subsection{National strategic documents on environmental protection in the financial perspective 2021-2027}

As a condition for a member state to receive Next Generation EU funds, it must be ratified and its own recovery plans must be prepared and sent to the European Commission. The Polish government ratified the EU document by developing and adopting the National Recovery Plan (NRP) in May 2021, which is a programmatic document outlining goals related to recovery and building Poland's socioeconomic resilience after the crisis caused by the COVID-19 pandemic. 
As per the RRF, the strategic objective of the NRP is to rebuild the development potential of the economy lost as a result of the pandemic and to support the building of sustainable competitiveness of the economy and increase the standard of living of the population in the long term, which will be done in particular by accelerating the development of a low-carbon, closed-loop economy that makes responsible use of environmental resources, as well as digitally-based development (Ministry of Development Funds and Regional Policy, 2021a, p. 25).

The document formulates 3 specific objectives, which are: 1) qualitative, innovative development of the economy leading to an increase in its productivity, taking into account the digital transformation of the country and society; 2) green transformation of the economy and development of green, intelligent mobility, objective 3) increase in social capital and quality of life, in particular by ensuring improvement in the health of citizens and higher quality of education and skills adapted to the needs of a modern economy.

The horizontal objective of the NRP is to strengthen the social and territorial cohesion of the country.

The implementation of the program is based on five components around which reforms and investments will be focused (Ministry of Development Funds and Regional Policy, 2021a, p. 26):

- economic resilience and competitiveness;

- green energy and reduction of energy intensity;

- digital transformation;

- efficiency, accessibility and quality of the health care system

- green, intelligent mobility.

Poland is to receive over EUR 23.9 billion in grants and over EUR 34.2 billion in loans. According to the adopted plan, the largest amount of funds is to be allocated for the implementation of the second and fifth component, related to environmental activities. A total of EUR 21.831 billion is to be allocated for investments in this area, including EUR 12.514 billion in grants and EUR 9.317 billion in loans.

Under Component Two (Green Energy and Reducing Energy Consumption), implementation processes are to focus on activities related to energy transformation, aiming to decrease the share of coal in the energy consumption structure to no more than 56\% in 2030, and to increase capacity obtained from renewable energy sources (RES) based on energy obtained from offshore wind farms, development of intelligent energy infrastructure, energy storage, hydrogen technologies. An important challenge is to improve air quality. Exceedances of permissible levels of pollution, mainly due to particulate matter PM10 and PM2,5, nitrogen dioxide and benzo(a)pyrene, are still recorded, especially in autumn and winter. Reduction of pollution will require further and faster changes in the area of energy improvement of buildings through changing the heating method, thermomodernisation, installation of photovoltaic panels or solar collectors. 
Within this component it is assumed that the existing legislative work and the already adopted programmes will be continued. The Ministry of Climate and Environment remains the institution responsible for implementation of reforms, while the National Fund for Environmental Protection and Water Management remains the implementing entity for investment projects.

In the grant part of the component the estimated cost is EUR 5,696 million, and from the loan part EUR 8,617 million (Ministry of Development Funds and Regional Policy, 202la, p. 175, 356).

Activities under Component Four, Green, Smart Mobility, are expected to address two key issues: 1) increasing the share of zero and lowcarbon transport and counteracting and reducing the negative impact of transport on the environment, 2) increasing transport accessibility, safety and digital solutions. In this area, legislative activities and investment projects are intended to continue the existing reforms based on the provisions of program documents: Strategy for Responsible Development up to 2020 (with an outlook up to 2030) (Resolution No. 8, 2017) and Strategy for Sustainable Transport Development up to 2030 (Resolution No. 105, 2019), with complementary sectoral development programmes: National Railway Programme (Council of Ministers, 2015), National Roads Construction Programme (Resolution No. 156, 2015), White paper of the unmanned aerial vehicle market: $u$-space, market, vision of development (PIE, 2019), Development program of Polish seaports until 2030 (Resolution No. 100, 2019).

Changes in transportation infrastructure are necessary, by increasing the number of low- and zero-emission rolling stock in urban and regional public transportation, its digitalization, modernization of services through support for traffic and rail transportation management systems (e.g. ERTMS), IT and organizational solutions that foster interbranch integration of transportation, broad digital information for users (e.g. investment in national ticketing and billing systems). Implementation of this component will require increasing the share of vehicles powered by alternative fuels, including through support for activities that increase the availability of vehicles powered by alternative fuels, expanding charging infrastructure, replacing buses with zero- and low-emission ones, and enabling the introduction of zero-emission zones in cities.

The institution responsible for implementing the investment will be the Ministry of Climate and Environment (leader) in cooperation with the Ministry of Infrastructure (partner).

The cost of component four on the grant side has been estimated at EUR 6,818 million and on the loan side at EUR 700 million (Ministry of Development Funds and Regional Policy, 2021a, p. 303, 446).

It should be clearly noted that the reform program and investments presented in the NRP are the result of already adopted and currently valid systemic solutions. The vast majority of the programs were in force in the completed financial perspective 2014-2020. As a result of varying degrees of implementation, the programs and measures will continue in the new EU financial perspective. However, they undoubtedly require legislative and formal clarification 
and financial guarantees for potential beneficiaries. Hence, it is the responsibility of public administration to efficiently prepare procedural solutions so that applicants can efficiently obtain funds for planned investments.

Consultations on the Partnership Agreement for 2021-2027 are currently underway. According to information posted on the European Funds website, about 40 percent of cohesion policy funds will be invested in regional programs managed by voivodeship marshals. 75 percent of this money has already been distributed, and 25 percent has been earmarked for a program reserve to be distributed during the negotiations of program contracts (Ministry of Development Funds and Regional Policy, 2021b).

\section{Methods}

In order to achieve the goal formulated in the introduction, it was necessary to present a basic division of funding sources for environmental protection tasks. In the following part, the multiannual financial framework of the European Union for 2021-2027, its pillars and planned amounts were presented.

In addition to the basic budget of the Union, a new instrument related to the socio-economic reconstruction of EU countries - the Next Generation EU - was indicated. A National Plan for Reconstruction and Increasing Resilience was prepared at the national level. Similarly, its pillars were indicated along with the amounts, in particular those for projects related to environmental protection. The amounts adopted in the new financial perspective 2021-2027 were compared with the perspective 2014-2020.

In the research process, the author reviewed and evaluated the literature on the sources of financing environmental projects as well as critically assessed the analysed documents related to the new European Union programming period 2021-2027.

\section{Results}

In the financial perspective 2014-20201, the implementation of European funds was based on strategic documents of the Union - Europe 2020 strategy (European Commission, 2010) and national - including the National Development Strategy to $2020^{2}$ (Ministry of Regional Development ${ }^{3}$, 2012) and nine integrated strategies on innovation, transport, human capital, social capital, energy and environment, state efficiency, regional development, agricultural development and rural areas. The Europe 2020 document sets out three main priorities:

1 The perspective has ended temporarily, but projects are still settled according to the $\mathrm{n}+2$ rule.

2 The document was replaced in 2016 with the Strategy for Responsible Development until 2020 (with an outlook until 2030) (Resolution No. 8, 2017).

3 The current thematic areas of the Ministry of Development are implemented by the Ministry of Funds and Regional Policy. 
smart growth based on the transformation of the economy through knowledge and innovation; sustainable growth aimed at using natural resources in an environmentally friendly way; and inclusive growth based on the creation of new jobs in the economy.

In the past perspective, Poland received a record amount of EUR 82.5 billion and an additional EUR 252 million to support unemployed youth. The granted funds were implemented under the following operational programs: Intelligent Development, Digital Poland, Eastern Poland, Knowledge, Education, Development, Technical Assistance, European Territorial Cooperation Programs (Table 2). Regional Operational Programs were given an amount of EUR 76.8 billion. The largest operational program was the Infrastructure and Environment (OPI\&E) program with a total amount of EUR 27,513.9 million (OPI\&E, 2020).

The funds were allocated to supporting the low-emission economy, environmental protection, including counteracting and adapting to climate change, transport, energy security, as well as health protection and cultural heritage. The main emphasis was placed on the reduction of emissions and support for the economy that efficiently uses the available resources, thus favoring the environment and at the same time more competitive. The beneficiaries of the program were public entities, including local government units and enterprises.

The program was financed from three sources: the European Regional Development Fund, from which EUR 4.97 billion was allocated to the program, the Cohesion Fund with the amount of EUR 22.44 billion and national funds public and private, whose minimum commitment was 4.85 EUR billion (European Funds, 2020, p. 2).

At the end of April 2021, the allocation of funds under this program amounted to $98.8 \%$, which included activities and projects related to: energy $89.6 \%$, environment $97.2 \%$, transport $88.7 \%$, culture $97,4 \%$, health $92.1 \%$ and technical assistance 62.3\% (European Funds, 2020).

According to the information posted on the European funds portal under the 2014-2020 perspective, 620 calls for proposals were held for the activities covered by OPI\&E on April 30, 2021, with 4,102 applications worth over PLN 234 billion. As a result of competition procedures, 2,776 contracts were concluded for the value of over PLN 213 billion (OPI\&E, 2020). The allocation took the form of grants and loans.

In the new financial perspective 2021-2027, the following programs will be implemented in:

- European Funds for a Modern Economy — proposed budget: EUR 7.9 billion;

- European Funds for Infrastructure, Climate and Environment - budget: EUR 25 billion;

- European Funds for Digital Development — budget: EUR 2 billion;

- European Funds for Eastern Poland — budget: EUR 2.5 billion;

- European Funds for Social Development — budget: EUR 4.2 billion; 
- Technical Assistance for European Funds - budget: EUR 550 million;

- Just Transition Fund program - a new program dedicated to regions that will face negative social and economic effects of the transition from a coalbased economy to a sustainable economy, proposed budget: EUR 4.4 billion. Regional Programs - will be a continuation of operational programs from 2014-2020. The pool to be divided among all 16 programs amounts to EUR 28.4 billion.

In the 2021-2027 financial perspective, Poland is to receive EUR 76 billion.

Based on the Statistics Poland (2020, p. 10), total expenditure on environmental protection in 2019 amounted to PLN 12,415.2 million. Compared to the previous year, there was an increase in the amount spent by PLN 2,023 million. Comparing the years 2018-2019 to 2015, it should be clearly indicated that expenditure on environmental protection decreased respectively by: PLN 4,767.8 million in 2018 and by PLN 2,744.8 in 2019. Taking into account the pressure on activities aimed at environmental protection, which has been intensifying for years, the decrease in expenditure seems surprising and unjustified.

Analysing the structure of financing sources for environmental protection, it should be clearly indicated that own resources of municipalities and enterprises dominate, followed by ecological funds alternately with foreign resources. In 2019, own funds accounted for 53\% of environmental protection expenditures, environmental funds, loans and credits for $22 \%$, funds from abroad for $19 \%$. The central budget and other sources provided respectively about $1 \%$ and $4 \%$. Referring to the previously mentioned years, the structure of financing sources did not change, only their shares were different. In 2018, own funds accounted for $56 \%$ of environmental protection expenditures, foreign funds for $22 \%$, environmental funds, loans and credits for $17 \%$, and funds from the central budget and other sources for $1 \%$ and $4 \%$ respectively. In 2015, own resources accounted for less than $42 \%$, foreign resources $27 \%$, ecological funds $18 \%$, loans and credits $6 \%$, and resources from the central budget and other sources were less than $1 \%$ and $4.5 \%$.

This means that still the main source of funding for environmental protection are the financial resources of businesses and municipalities, which are the main investors in environmental protection (Table 3).

The institutional arrangements at the EU and national level appear to be following the developments in the area of the environment and implementing a number of measures aimed at protecting the environment in its various aspects. The proposed measures are followed by real financial resources. Yet, this is not enough. We live in an unstable 21st century. In an age where we are observng "active human interference in the processes that guide the geological evolution of the planet" at the beginning of the fourth industrial revolution. The world is accelerating. Politicians and scientists proclaim that nothing will be the same in the future. The pandemic crisis caused by the SARS-CoV-2 vi- 
rus has intensified the discussion on human-nature-economy relations (Śleziak, 2020, p. 227)

It is important for all countries in the European Union to join forces in defence of nature. Solving the problems associated with environmental pollution and climate changes requires appropriate strategies and programmes, good legislation and appropriate economic and financial instruments, including tax policy to support green transformation. What is also needed is systemic ecological education and the creation of good conditions for the operation of non-governmental organisations.

\section{Conclusion}

Strategic EU and national documents, indicating the necessary directions of development in the area of environmental protection, constitute the basis for defining systems and mechanisms supporting the development of pro-ecological investments aimed at minimizing the damage caused by aggressive human activity to nature.

Both in the financial perspective 2014-2020 and the new one for 20212027 , the issue of environmental protection is one of the main priorities. The continuation of the previous structural funds was retained, supplemented with new instruments responding to the unprecedented socio-economic situation as a result of the global health crisis caused by the SARS-CoV-2 pandemic. The outbreak of the pandemic in 2020 translated into the need to modify the existing procedures and schedule of work on the multiannual financial framework for 2021-2027 and to change the previously adopted assumptions. In response to the repeated lookout in the Member States, the closure of many branches of the economy forced the European Commission to prepare new financial instruments with the help of which it will be possible to rebuild the economic potential.

As a result of negotiations, Poland will receive EUR 76 billion under the EU cohesion policy and the Just Transition Fund, which is more than PLN 770 billion, while in the previous one it was EUR 85.2 billion.

The allocation of funds and the directions of spending will not only result from Poland's development needs, but also (or perhaps above all) from the modified EU priorities in response to the health situation of the EU community after the pandemic and the continuation of activities related to research, innovation, digitization, climate and the environment. After launching individual programs, it will be possible to carry out ongoing analysis and evaluation of both the solutions adopted in the strategic documents and their effects. It would be worthwhile for decision-makers to unequivocally work out economic and financial solutions that will encourage environmentally friendly investments. On the other hand, a series of educational measures should be undertaken right away, so that our awareness of the need to care for the planet could grow as quickly as possible. 


\section{References}

Augusewicz, A., Breńko, T., Kozłowska, A., Miłaszewski, R., Karolinczak, B., Werner-Juszczuk, A., \& Winiarek, P. (2012). Ekonomiczne aspekty ochrony środowiska. Budownictwo i Inżynieria Środowiska, 3(1), 17-23.

Barczak, A., \& Kowalewska, E. (2014). Źródła finansowania zadań z zakresu ochrony środowiska w Polsce: przegląd stosowanych rozwiązań. Prawo Budżetowe Państwa i Samorządu, 1(2), 37-58. http://dx.doi.org/10.12775/ PBPS.2014.003.

Burzyńska, D. (2012). Rola inwestycji ekologicznych w zrównowazonym rozwoju gmin w Polsce. Uniwersytet Łódzki.

Council of Ministers. (2015). Krajowy Program Kolejowy. Retrieved 15.05.2021 from https://www.gov.pl/web/infrastruktura/krajowy-program-kolejowy.

Council Regulation (EU, Euratom) 2020/2093 of 17 December 2020 laying down the multiannual financial framework for the years 2021 to 2027 (OJ L 433I , 22.12.2020).

Dobrzańska, B., Dobrzański, G., \& Kiełczewska, D. (2021). Ochrona środowiska przyrodniczego. PWN.

European Commission. (2010). Europe 2020: a strategy for smart, sustainable and inclusive growth. Retrieved 10.04.2021 from https://eur-lex.europa.eu/ legal-content/PL/TXT/?uri=celex\%3A52010DC2020.

European Commission. (2021a). The 2021-2027 EU budget: what's new. Retrieved 10.04.2021 from https://ec.europa.eu/info/strategy/eu-budget/ long-term-eu-budget/2021-2027/whats-new_en.

European Commission. (2021b). Recovery plan for Europe. Retrieved 10.04.2021 from https://ec.europa.eu/info/strategy/recovery-plan-europe_en.

European Council. (2021). Infographic: multiannual financial framework 20212027 and next generation EU. Retrieved 10.04.2021 from https://www.consilium.europa.eu/pl/infographics/mff2021-2027-ngeu-final.

European Funds. (2020). Stan wdrażania Funduszy Europejskich w Polsce w latach 2014-2020: nabory, wnioski o dofinansowanie, umowy, wnioski o ptatność. Retrieved 15.05.2021 from https://www.funduszeeuropejskie.gov.pl/ strony/o-funduszach/raporty/raporty-sprawozdania/stan-wdrazaniafunduszy-europejskich-w-polsce-w-latach-2014-2020-nabory-wnioskio-dofinansowanie-umowy-wnioski-o-platnosc.

Fiedor, B. (2002). Instrumenty ekonomiczne: przegląd i kryteria wyboru. In B. Fiedor (Ed.), Podstawy ekonomii środowiska i zasobów naturalnych (pp. 293342). C.H. Beck.

Gabryś, M. (2007). Znaczenie banków w finansowaniu ochrony środowiska w Polsce na przykładzie Banku Ochrony Środowiska S.A. In A. Nalepka (Ed.), Organizacje komercyjne i niekomercyjne wobec wzmożonej konkurencji i rosnących wymagań konsumentów, 6, 184-199. Wyższa Szkoła Biznesu w Nowym Sączu. 
Graczyk, A. (2002). Metody finansowania ochrony środowiska i ich zgodność z ogólnymi zasadami gospodarki rynkowej. In B. Fiedor (Ed.), Podstawy ekonomii środowiska i zasobów naturalnych (pp. 328-334). C.H. Beck.

Jura, J. (2015). Zasady finansowania przedsięwzięć proekologicznych. Budownictwo o zoptymalizowanym potencjale energetycznym. Construction of Optimized Energy Popential, 1(15), 85-90.

Kłos, L. (2015). Źródła finansowania ochrony środowiska w Polsce. Prace Naukowe Uniwersytetu Ekonomicznego we Wroctawiu, 395, 1290138. https://doi. org/10.15611/pn.2015.395.12.

Kożuch, M. (2007). Preferencje podatkowe jako element system finansowania ochrony środowiska w Polsce. Zeszyty Naukowe Akademii Ekonomicznej w Krakowie, 732, 109-122.

Kożuch, M. (2018). Zmiany w finansowaniu przedsięwzięć ochrony środowiska przyrodniczego w Polsce. Zeszyty Naukowe Uniwersytetu Ekonomicznego $w$ Krakowie, 1(973), 61-78. https://doi.org/10.15678/ ZNUEK.2018.0973.0104.

Macherzyński, B., \& Nowodziński, P. (2017), Ekoinnowacje jako instrument zarządzania w przedsiębiorstwach. In D. Jelonek, \& P. Nowodziński (Eds.), Sektor nowoczesnych ustug dla biznesu: fundament rozwoju miasta, regionu, uczelni (pp. 53-60). Oficyna Wydawnicza Stowarzyszenia Menedżerów Jakości i Produkcji.

Ministry of Development Funds and Regional Policy. (2021a). Krajowy plan odbudowy i zwiększania odporności. Retrieved 15.05.2021 from https://www. gov.pl/attachment/2572ae63-c981-4ea9-a734-689c429985cf.

Ministry of Development Funds and Regional Policy. (2021b). Umowapartnerstwa 2021-2027. Retrieved 18.05.2021 from https://www.funduszeeuropejskie. gov.pl/media/97650/umowa_partnerstwa_broszura_wersja_dostepna.pdf.

Ministry of Regional Development. (2012). Strategia rozwoju kraju 2020. Retrieved 10.04.2021 from https://rpo2007-2013.slaskie.pl/zalaczn iki/2014/01/17/1389965536.pdf.

OPI\&E. (2020). Sprawozdanie miesięczne z realizacji Programu Operacyjnego Infrastruktura i Środowisko. Retrieved 15.05.2021 https://www.pois.gov.pl/ media/97451/Informacja_miesieczna_grudzien_2020.pdf.

PIE. (2019). Biata księga rynku bezzatogowych statków powietrznych: u-space, rynek, wizja rozwoju. Retrieved 15.05.2021 from https://pie.net.pl/wp-content/uploads/2019/02/Bia\%C5\%82a_Ksi\%C4\%99ga_Bezza\%C5\%82ogowych_Statk\%C3\%B3w_Powietrznych.pdf.

Poskrobko, B. (1998). Zarządzanie środowiskiem. PWE.

Rubaszkiewicz, J. (2008). Ochrona środowiska $w$ wymiarze międzynarodowym i krajowym. Wyższa Szkoła Cła i Logistyki.

Rutkowska, M., \& Popławski, Ł. (2017). Instrumenty ekonomiczne w ochronie środowiska ze szczególnym uwzględnieniem ubezpieczeń ekologicznych. Studia i Prace WNEIZ US, 47(1), 47-55. https://doi.org/10.18276/ sip.2017.47/1-04. 
Statistics Poland. (2020). Economic aspects of environmental protection 2020. Retrieved 18.11.2021 from https://stat.gov.pl/download/gfx/portalinformacyjny/en/defaultaktualnosci/3303/4/3/1/economic_aspects_of_environmental_protection_2020.pdf.

Śleziak, C. (2020). Potrzebujemy wizji rozwojowych, zmiany reguł gry oraz więcej współpracy. In W. Szymalski (Ed.), 100 lat ochrony środowiska w Polsce. Instytut Naukowo-Wydawniczy „Spatium”.

Treaty of Lisbon amending the Treaty on European Union and the Treaty establishing the European Community (OJ C 306, 17.12.2007).

Uchwała nr 100 Rady Ministrów z dnia 17 września 2019 r. w sprawie przyjęcia programu pod nazwą „Program rozwoju polskich portów morskich do 2030 roku" [Resolution No. 100 of the Council of Ministers of 17 September 2019 on the adoption of the programme entitled "Programme for the development of Polish seaports until 2030"] (M.P. 2019 poz. 1016) (Poland).

Uchwała nr 105 Rady Ministrów z dnia 24 września 2019 r. w sprawie przyjęcia Strategii Zrównoważonego Rozwoju Transportu do 2030 roku [Resolution No. 105 of the Council of Ministers of 24 September 2019 on the adoption of the Strategy for sustainable transport development until 2030] (M.P. 2019 poz. 1054) (Poland).

Uchwała Nr 156 Rady Ministrów z dnia 8 września 2015 r. Program Budowy Dróg Krajowych na lata 2014-2023 (z perspektywą do 2025 r.) [Resolution No. 156 of the Council of Ministers of 8 September 2015. Programme for the Construction of National Roads 2014-2023 (with an outlook until 2025)]. Retrieved 15.05.2021 https://www.gov.pl/attachment/ a777a659-1517-4e5c-bb89-dea98a400187.

Uchwała nr 8 Rady Ministrów z dnia 14 lutego 2017 r. w sprawie przyjęcia Strategii na rzecz Odpowiedzialnego Rozwoju do roku 2020 (z perspektywą do 2030 r.) [Resolution No. 8 of the Council of Ministers of 14 February 2017 on the adoption of the Strategy for Responsible Development until 2020 (with an outlook until 2030)] (M.P. 2017 poz. 260) (Poland).

Wasiuta, A. (2015). Ekonomiczne instrumenty polityki ekologicznej w kontekście zarządzania środowiskowego. In T. Noch, \& J. Saczuk (Eds.), Wspótdziatanie systemu zarządzania $i$ inżynierii produkcji: teoria $i$ praktyka (pp. 223-246). Gdańska Szkoła Wyższa.

\section{Acknowledgements}

Author contributions: author has given an approval to the final version of the article.

Funding: this research was fully funded by the author's own sources.

Note: the results of this study were presented at the 8th International Conference Sustainable Finance \& Accounting: Economy, Ethics, Environment (April 19-21, 2021, Toruń, Poland). 


\section{Appendix}

Table 1.

Multiannual financial framework 2021-2027 total allocations per heading (in EUR bln)

\begin{tabular}{lccr}
\hline \multicolumn{1}{c}{ Specification } & MFF & Next generation EU & Total \\
\hline 1. Single market, innovation and digital & 132.8 & 10.6 & 143.4 \\
2. Cohesion, resilience and values & 377.8 & 721.9 & 1099.7 \\
3. Natural resources and environment & 356.4 & 17.5 & 373.9 \\
4. Migration and border management & 22.7 & - & 22.7 \\
5. Security and defence & 13.2 & - & 13.2 \\
6. Neighbourhood and the world & 98.4 & - & 98.4 \\
7. European public administration & 73.1 & 750.0 & 73.1 \\
total MFF & 1074.3 & & 1824.3 \\
\hline
\end{tabular}

Notes:

All amounts in EUR billion, in constant 2018 prices.

Source: European Commission (2021b).

Table 2.

EU funds in 2014-2020 and amounts (in EUR mln)

\begin{tabular}{lr}
\hline \multicolumn{1}{c}{ Fundus } & Amount \\
\hline 1. Infrastructure and Environment & 27513.9 \\
2. Intelligent Development & 8614.1 \\
3. Digital Poland & 2255.6 \\
4. Eastern Poland & 2117.2 \\
5. Knowledge, Education, Development & 4419.3 \\
6. Technical Support & 700.1 \\
7. European Territorial Cooperation & 700.0 \\
\hline
\end{tabular}

Source: Own preparation based on OPI\&E (2020).

Table 3.

Expenditures on environmental protection by sources of financing (in PLN mln)

\begin{tabular}{lrrr}
\hline \multicolumn{1}{c}{ Specification } & \multicolumn{1}{c}{2015} & \multicolumn{1}{c}{2018} & 2019 \\
\hline total & 15160.0 & 10392.2 & 12415.2 \\
own funds & 6310.3 & 5809.9 & 6572.3 \\
funds from the state budget: & 241.3 & 146.2 & 150.1 \\
from voivodship budgets & 56.0 & 63.3 & 39.4 \\
from district budgets & 18.1 & 18.4 & 11.7 \\
from municipality budgets (share) & 152.5 & 105.3 & 138.3 \\
funds from abroad & 4082.6 & 2263.5 & 2414.9 \\
ecological funds (loans, credits and grants) & 2700.8 & 1075.4 & 1427.7 \\
domestic credits and loans, including bank credits and loans) & 927.7 & 694.7 & 1344.5 \\
other funds, including non-financed outlays & 670.7 & 215.5 & 316.3 \\
\hline
\end{tabular}

Source: Own preparation based on Statistics Poland (2020, pp. 40-46). 


\section{Scheme 1 .}

Instruments for financing environmental protection

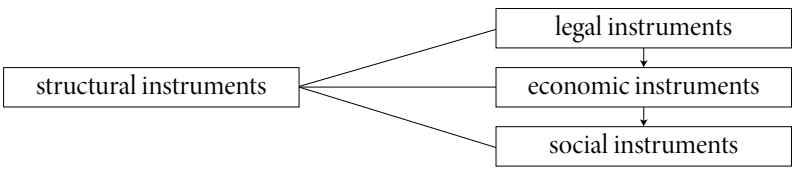

Source: Wasiuta (2015, p. 224).

Scheme 2.

Economic instruments in environmental protection

\begin{tabular}{|c|l|l|}
\hline eco-taxes and eco-fees & $\begin{array}{l}\text { - charges for the emission/discharge of wastewater } \\
\text { - charges for using the environment } \\
\text { - service fees }\end{array}$ \\
- administrative fees \\
- product fees \\
- concession fees
\end{tabular}

Source: Wasiuta (2015, p. 231). 
